\title{
HELPING STUDENTS OF ARABIC DEPARTMENT OR PESANTREN LEARN THE ENGLISH DERIVATION
}

\author{
Handoko
}

Email: hokondok@yahoo.com

STAI Ma'had Aly Al-Hikam Malang

Alamat Korespondensi: Arga Park kav. 4 Jalan Nusa Indah Atas, Malang 65141

\begin{abstract}
Presenting the comparative description of English derivation and Arabic derivatives, this paper is intentionally purposed to help students to understand the English derivation. Most of students, especially the students of Arabic department or students who are familiar with Arabic as they have learned before, regard that English language is difficult to learn. To solve this problem, the writer provides a comparative study by using Arabic as another language that he knows. This paper constitutes an exploratory study of derivatives in both English and Arabic, provides procedures in teaching English derivation to the students who have basic knowledge in Arabic, and then gives reflection and conclusion..
\end{abstract}

Keywords: students of Arabic department, English derivation, Arabic derivatives

\section{HEADING 1}

A process whereby the addition of affixes, chiefly prefixes and suffixes in English, to base forms results in the creation of new words, derivation. Compare to Arabic derivatives, English derivation has some similarities in inflection affix that can be found in Arabic. Through this comparison, students of non-English department, Arabic one are expected to be easier learning the English derivation.

\section{DERIVATION COMPARISON IN USE}

Victoria Fromkin in the book: $A n$ Introduction to Language (1974, p. 121) asserted that derivation is the forming of new words by combining derivational affixes or bound bases with existing words.

Affixation is viewed as a process of producing a new meaning or making grammatical contrast by modifying a base. O'Grady and Dobrovolsky (1992, p.121) state that linguist break affixes into three types. The first one is called prefix in which an affix is attached to the the front of its base such as rein reread, un- in unkind, and dis- in dissapear. The second one is known as suffix in which an affix is added to the end of its base such as -ish in foolish, -ly in badly, and -ment in payment. The last type is infix which occurs within a base. Prefix and suffix commonly occur in English and Arabic while infix can be found not only in Philippine language, Tagalog and Indonesian but also Arabic.

The most common word formation process to be found in the production of the new Arabic word whose process is called derivation. In Arabic, the part that concerns and talks about the change of word form in forming the new word is called عِلْمُ الصَّرَّف or عِلْمُ النَّْْرِيْفِ. Muhammad Ma'sum Ibnu Ali (1965, p. 141) in his book entitled Al-Amsilah al-Tashrifiah described the Arabic derivatives and classified it into two big different process as it is seen from the source of being word (tashrif al-isthilahi) and tashrif al-lughowi in which the new word is created because of dhamir (subjective pronoun).

A part form any different point of view of word source: verb (fi'il) or noun (masdar), Arabic derivatives are form one word develops into 11 kinds of words come along with 14 pronouns constituting an important role in Arabic derivatives. But certain words 
such as fi'il al-amr (command verb), fi'il alnahyi (prohibition verb) have only six pronouns. The fourteen pronouns make similar form toward their forming the new words. It is more comprehensive word interrelatedness than English which has 13 derivational affixes consist of 9 suffixes and 4 prefixes with 7 pronouns only.

Based on the etymology and its derivation process, the Arabic derivatives probably described as:

Mujarrod, the source of its word means "naked" which shows the condition that is still pure and has not got any change of affixation. In one thing it seems like "original word or free morpheme" according to English structure even though it is not exactly the same.

Mazidah, is the word in which the composition of its letter is not original anymore. It is caused by the additional of the letter inserting in the beginning or in the middle of that word.

In contrast of English derivational affixes which are English derivational patterns and their suffixes and prefix stated above, Arabic derivational affixes with its letters hurf al-hijaiyah, which can be used to change the word mujarradah into mazìdah arel, ورنس and multiply the certain letter with harakat syaddah ( $)$.).

The use of those letters are divided into two, used alone (only one letter) such as أَجْلَسَن in the form of أَفْعَلَ and used not only one letter but more such as إِِنَiْفَرَ in the form of

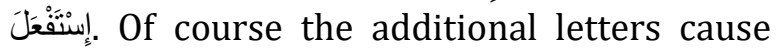
the different effect to the original word in which the pattern of form change involved or even the meaning after derived into new word.

The pattern in which kalimat almujarradah (original word) is derived into mazìdah (not original one) has fifteen forms, twelve are used in kalimat al-mazidah which is derived from mujarradat al-tsulasiyah (an original word which is constructed by three letters) and three forms are used in kalimah mazìdah, which is derived from mujarradat alrubaiyah (an original word which is constructed by four letters).

In short, Arabic derivatives which are lexically inclined by the morphological process emphasize on the process of derivatives and the cause of being word form: sources, affixes and doer action or subjective pronoun.

For example; in English structure, a word such as "work" can be changed into the new one like "worker". That word though derived from the same root "work' but has different meaning which influences the use of composing sentences. It also happens that in process of Arabic derivatives, for example: عَامِلْ (work) derives into a new word (worker).

The cause which has an important role informing the new word is affixes. There are same certain Arabic alphabet with the way of their own and differentiate whether it is transitive or not such as جَلَسن (sit down) مجلس جَالَسن (make it to sit) and مجلَن (seat) and so on.

The other reason why a word can derive into a new one is because the different doer action or number of persons (singular or plural) that are implied in the word, like جَلَّن etymologically means "sit down" and the one who sits must be third male person such as Ali. But if the subject is changed by the third female person like Fatimah, the verb جَلَّن will have a new form جَلَسَتْ . Also in the verb جَلَسًَا (the subject is two male persons) will derive into the form جَلَسُوْ ا which indicates plural of doer action (more than two persons). This is the last part of Arabic derivatives named as tashrif al-lughowi, which concerns in creating the new word as the result of different subject forming (subjective pronoun).

Comparing to English derivational affixes, simple sentence is provided in Arabic with briefly explanation as follow:

Kataba al-kāthibu kitābatan bi al-maktābi 'ala al-maktabi.

wrote-the writer-writing-using tool of writing on the place of writing.

Kataba (wrote) is originally form of word which derives into käthibun (writer) as ism alfä'il (subject). The use of 'al' as an article which indicates definitive writer (the). kitābatan (writing) is ism al-mashdar (noun), something not definitive which can be paper, book or somewhat written instead as an object. Almiktābu is ism al-ālat (tool) to write in which the change of end of vowel: $u-i$ as the result of preposition (harfal-jer) bi (by). Al-maktabu is a place on where the activity of writing is conducted. It is ism al-makān (setting of place) 
which is always preposition (harf al-jer) 'ala (on) lies before.

Unlike verb-to-noun (concrete) as in the word writer: write $\rightarrow$ writer with suffix 'er', kathibun is derived from the second verb or past (kataba), which a prefix is I, it can be seen that the change is started by separating the first letter with long vowel "a" and second letter is in vowel " $\mathrm{i}$ " then ended by tanwin of vowel " $u$ " at the last letter. In contrast of the word writing that is intended with the process of inflection, which uses another kind of affix in order to form variants of the same word, as with write $\rightarrow$ write-ing (gerund), kitäbatan is ism al-mashdar (noun); the word كiئب changes into كِنَّابٌ by starting the vowel "i: at the beginning letter is followed by separated second letter with long vowel "a" and ended by tanwin of vowel "u" at the last letter. As an object, it ends with fathatain. Whilst, Almiktābu; the change which happens in this last new word as a product of Arabic derivatives is formed by prefix ? which makes a zero vowel to the next letter followed by separated long vowel "a" and ended by tanwin of vowel " $\mathrm{u}$ " at the last letter if it is free from harf al-jer (preposition). In English version this kind of writing tool is ended by suffix ing like a place of writing, al-maktabu is constructed by adding the prefix ? with the vowel "a" makes a zero vowel to the next letter followed by vowel "a" at the third letter and ended by tanwin of vowel " $\mathrm{u}$ " at the last letter (كتَبَ (مَكْنَبٌْ

\section{TEACHING PROCEDURES \\ Pre-Teaching}

1. Ask the students to give examples of Arabic derivatives which derivational affixes are used to form new words such as ism al-mashdar (noun), ism al-fä'il (subject), ism al-älat (tool), and ism almakān (setting of place) in simple statements. After the students write the examples, the teacher can do the activities as follows:

\section{Whilst-Teaching}

2. Analyze students' work and then explain about derivational affixes which consist of 4 prefixes and 9 suffixes. In this phase, the teacher compares English derivation and Arabic derivatives.

3. Divide students into some groups and then discuss the derivational affixes elements between English derivation and Arabic derivatives.

4. After understanding the derivational affixes, ask the students to find the similarities and differences of two languages as derivative elements comparison.

5. Ask the students to write derivational affixes: prefix and suffix in simple statements based on their sentences at the beginning assignments as a comparative study.

6. Ask each of groups to present their work and the other groups give comments or questions.

\section{Post-Teaching}

7. Give feedback to the students.

\section{REFLECTION}

In his Synthesis in Language Teaching, Hammery (1982) in Teaching English with Insights from Linguistic (2009, p. 59) stated that to love second language teaching or learning, it is necessary to try various teaching techniques with the hope that something will work. Since teaching a second language to students in different department remains a great challenge, it requires not only courageous, well-determined, and committed teachers but also creative and innovative teaching techniques (Hussin, Maarof, et al. Paper for The Millennium MICELT 2000, 3rd Malaysia International Conference for English Language Teaching, Melaka. Universiti Putra Malaysia). It is also important to select a method or technique based on any linguistic theory that the teacher is truly familiar. Teaching English derivation by providing a comparative study which uses Arabic as another language the teacher knows is intended to help students to understand the origin of English with its derivation. This technique is interesting to be applied for the beginners, especially the students of Arabic department or students of boarding school who have basic knowledge in Arabic language.

\section{CONCLUSION}

This paper has shown that a comparative description of English derivation and Arabic derivatives is one available technique to help students to learn. It is expected that by using this teaching process, 
the students can understand the English

derivation easily.

\section{REFERENCE}

Ali, Muhammad Ma'sum Ibnu (1965). Al-Amsilah al-Tashrifiah. Semarang: Pustaka Alawiyah.

Bawani, Imam (1978). Tata Bahasa Arab. Surabaya: Al-Ikhlas.

Cahyono, Bambang Yudi (2009). Teaching English with Insights from Linguistics: Helping Learners Learn English Be As A Copulative Elements. ed.. State University of Malang Press.

Crystal, David (1999). The Penguin Dictionary of Language. England: Penguin Books.

Fromkin, Victoria (1974). An Introduction to Language. LA: University of California.

Hammerly, H (1982). Syntesis in Language Teaching: An Introduction to Linguistics. Blaine, WA: Second Language Publications.

Hussin, Supyan, Nooreiny Maarof, and J. V. D'Cruz. (2000). Sustaining an Interest in Learning English and Increasing the Motivation to Learn English: An Enrichment Program. Paper for The Millennium MICELT 2000, 3rd Malaysia International Conference for English Language Teaching, Melaka. Universiti Putra Malaysia. http://iteslj.org/Techniques/HussinMotivation/

O’Grady, W., \& Dobrovolsky, M. (1992). Contemporary Linguistic Analysis. Toronto: Copp Clark Company. 